\title{
ANALISIS PEMBELAJARAN IPA SELAMA MASA PANDEMI COVID-19 UNTUK AKSELERASI MERDEKA BELAJAR DI SEKOLAH DASAR
}

\author{
Rose Andriyani Saputri \\ Universitas Sebelas Maret (UNS) Surakarta Jawa Tengah, Indonesia \\ Email: rsandriani@gmail.com
}

\begin{abstract}
Abstrak
Pandemi covid-19 menjadikan Indonesia mengalami berbagai krisis baik di sektor ekonomi maupun pendidikan. Sekolah yang selama ini melakukan pembelajaran secara konvensional harus berailih ke pembelajaran yang lebih modern dengan memanfaatkan kemajuan teknologi yang sudah tersedia. Salah satu pelajaran yang dianggap cukup sulit untuk diterapkan dalam pembelajaran daring adalah mata pelajaran IPA. Pemerintah mencoba mencari solusi akibat pembelajaran daring yang berdampak pada kualitas pembelajaran di sekolah dasar, salah satunya dengan meluncurkan berbagai program yang mendukung pembelajaran daring melalui Merdeka Belajar. Penelitian ini bertujuan untuk menganalis pelaksanaan pembelajaran daring pada pembelajaran IPA di sekolah dasar selama pandemi covid-19 dengan mengkaitkannya dengan program pemerintah saat ini yaitu Merdeka Belajar. Metode penelitian yang digunakan adalah deskriptif kualitatif dengan teknik pengumpulan data melalui kuesioner menggunakan metode CRI (Certainly of Response Index) pada guru sekolah dasar sebagai sampel penelitian yang dipilih berdasarkan purposive sampling. Hasil penelitian menunjukan selama pembelajaran IPA secara daring masih banyak kekurang ditemukan, sehingga belum mampu mengakselerasi Merdeka Belajar secara maksimal. Hal ini menjadi alasan perlu adanya perbaikan yang dilkukan guru agar pembelajaran IPA yang dilakukan secara daring dapat berjalan dengan maksimal sehingga dapat mengakselerasi merdeka belajar.
\end{abstract}

Kata Kunci: pembelajaran; IPA; daring; merdeka belajar

\section{Abstract}

The covid-19 pandemic has left Indonesia experiencing various crises in both the economic and education sectors. Schools that have been doing conventional learning must move to more modern learning by utilizing technological advances that are already available. One lesson that is considered quite difficult to apply in online learning is IPA subjects. The government is trying to find solutions due to online learning that have an impact on the quality of learning in elementary schools, one of which is by launching various programs that support online learning through Merdeka Belajar. This research aims to analyze the implementation of online learning in IPA learning in elementary schools during the covid-19 pandemic by linking it to the current government program, Merdeka Belajar. The research method used is descriptive qualitative with data collection techniques through questionnaires using the CRI (Certainly of Response Index) method for elementary school teachers as research samples selected based on

$\begin{array}{ll}\text { How to cite: } & \text { Saputri, R. A., (2021) Analisis Pembelajaran IPA Selama Masa Pandemi Covid-19 untuk Akselerasi } \\ & \text { Merdeka Belajar Di Sekolah Dasar. Syntax Idea, 3(9), https://doi.org/10.36418/syntax-idea.v3i9.1482 } \\ \text { E-ISSN: } & \text { 2684-883X } \\ \text { Published by: } & \text { Ridwan Institute }\end{array}$


purposive sampling. The results of the study show that during science learning boldly there are still many found, so that they have not been able to accelerate the independence of learning to the fullest. This is the reason for the need for improvements made by teachers so that science learning that is carried out boldly can run optimally so that it can accelerate independent learning.

Keywords: learning; IPA; Daring; Free to learn

Received: 2021-08-22; Accepted: 2021-09-05; Published: 2021-09-20

\section{Pendahuluan}

Indonesia di akhir tahun 2019 mengalami krisis di berbagai sektor kehidupan masyarakatnya, salah satunya di sektor pendidikan. Hal ini dikarenakan munculnya wabah yang secara misterius menyebar di Wuhan, Cina. Sejak 31 Desember 2019 hingga 3 Januari 2020 kasus ini meningkat pesat, ditandai dengan dilaporkannya sebanyak 44 kasus. Tidak sampai satu bulan, penyakit ini telah menyebar di berbagai provinsi lain di China, Thailand, Jepang, dan Korea Selatan (Susilo et al., 2020). Virus ini dikenal dengan Covid-19, virus ini dengan mudah menyebar antara manusia ke manusia sehingga meyebabkan ledakan pasien akibat virus ini. Kebanyakan pasien mengalami gejala sesak napas yang dapat menjadi gawat ketika pasien memiliki riwayat penyakit, seperti asma, autoimun, dan penyakit bawaan lainnya (Purnamawan, 2021). Tindakan pencegahan yang utama adalah membatasi aktivitas kelompok yang berisiko tinggi selama masa inkubasi. Upaya pencegahan lainnya adalah meningkatkan kapasitas pemulihan tubuh dengan makan makanan yang lebih sehat, mencuci tangan lebih sering, memakai masker di tempat-tempat berbahaya atau ramai, berolahraga, istirahat yang cukup, dan makan makanan yang dimasak. Jika Anda sakit, harap segera pergi ke rumah sakit rujukan untuk pemeriksaan (Davies, 2002). Menaggulangi penyebaran virus tersebut pemerintah memerintahkan untuk meliburkan proses kegiatan belajar mengajar selama wabah masih berlangsung di Indonesia. Sayangnya wabah tidak dapat berhenti dengan cepat hingga akhirnya pemerintah meminta sekolah tetap melakukan pembelajaran namun dengan sistem daring (dalam jaringan) dimana pembelajaran dapat berlangsung tanpa adanya interaksi fisik antara guru dan siswa. Dalam Undang-Undang No. 20 tahun 2003 pasal 1 ayat 20 tentang sistem pendidikan nasional dijelaskan bahwa pembelajaran adalah proses interaksi peserta didik dan sumber belajar pada suatu lingkungan (Depdiknas, 2003).

Pembelajaran menjadi suatu aktivitas yang dilakukan dengan melalui berbagai proses agar tercipta pembelajaran yang ideal antara guru dan siswa. Proses pembelajaran berlangsung seumur hidup dan dapat diterapkan kapan saja, di mana saja. Belajar dan belajar memiliki arti yang sama, tetapi memiliki arti yang berbeda Perancangan, pelaksanaan, dan evaluasi, dimaknai sebagai interaksi peserta didik dengan pendidik dan sumber belajar dalam lingkungan belajar (Absari, 2020). Tiga komponen tersebut merupakan penunjang dalam keberhasilan suatu proses pembelajaran. Ada banyak teori yang bisa digunakan untuk menjadi landasan dalam konsep pembelajaran diantaranya teori Ilmu Jiwa Daya yang beranggapan bahwa jiwa 
manusia mempunyai daya-daya sperti daya mengenal, daya mengingat, daya berpikir, daya fantasi yang dapat dipertajam secara fungsional untuk sesuatu hal dengan cara melatih semua daya yang tersedia (Hanafy, 2014). Hal ini membuat guru mengalami kesulitan salah satunya ketika hendak melakukan pembelajaran IPA, karena dalam pembelajaran IPA tidak hanya aspek kognitif saja yang ditekankan namun juga sikap dan keterampilan proses sainsnya.

IPA tidak hanya mengatur kumpulan pengetahuan yang berupa fakta, konsep, atau prinsip, tetapi juga mengatur proses penemuan. Melalui pembelajaran IPA siswa diharapkan dapat menggunakan keterampilan berpikir untuk menyelesaikan masalah dalam kehidupan sehari-hari, yang dapat dilakukan dengan membaca buku, menggunakan media digital untuk memperoleh informasi yang berkaitan dengan sains dan melakukan studi observasional tentang alam (Maison et al., 2020). Pendidikan IPA adalah tindakan yang membantu siswa lebih memahami lingkungan. IPA memberikan siswa pengalaman langsung terhadap pemahaman ilmiah tentang lingkungan, yang membantu mengembangkan keterampilan kognitif, psikomotor, dan berpikir sosial. Pembelajaran IPA mencakup rangkaian pengetahuan berupa fakta, konsep dan prinsip, serta proses penemuan. Penelitian ilmiah menekankan pada pengalaman langsung peserta didik untuk mengembangkan potensinya, sehingga peserta didik dapat memahami lingkungan alam dan menemukan apa yang membantu peserta didik memperoleh pengalaman di lingkungan. Namun di masa pandemi, IPA harus diajarkan secara online atau mandiri oleh siswa (Handayani \& Jumadi, 2021).

Teknologi dapat dimanfaatkan dalam kegiatan proses belajar mengajar, yang merubah sistem pembelajaran yang selama ini bersifat konvensional berubah ke arah yang lebih modern (Sourial et al., 2018). Peserta didik dapat mengakses materi pelajaran dan mengirim tugas dari rumah masing-masing. Peserta didik dapat mendapatkan materi pelajaran tanpa bertemu dengan guru secara fisik di sekolah (Sadikin \& Hamidah, 2020). Pemerintah juga mengambil peran dalam menangani ketimpangan kegiatan belajar selama pandemi covid 19 ini. Terdapat 12 platform atau aplikasi yang bisa diakses pelajar untuk belajar di rumah yaitu (1) Rumah belajar; (2) Meja kita; (3) Icando; (4) Indonesiax; (5) Google for education; (6) Kelas pintar; (7) Microsoft office 365; (8) Quipper school (9) Ruang guru; (10) Sekolahmu; (11) Zenius; (12)Cisco webwx (Sourial et al., 2018).

Penelitian sebelumnya yang membahas tentang situasi pembelajaran IPA siswa sekolah dasar dengan metode Pembelajaran Daring selama masa wabah Covid-19, menunjukan bahwa perubahan metode pembelajaran seperti metode ceramah, metode diskusi, tanya jawab, eksperimen, demontrasi yang dilakukan secara langsung tatap muka oleh guru dengan peserta didik menjadi pembelajaran dengan menggunakan metode daring akibat pandemi Covid-19 menimbulkan masalah baru dalam proses belajar mengajar diantaranya, situasi pembelajaran kurang efektif, sulitnya guru dalam menyampaikan materi yang dikombinasikan dengan praktikum ,serta materi dengan perhitungan, keterbatasan orang tua peserta didik dalam membeli paket data dan jaringan kurang bagus (B \& Ramli, 2021). 
Penelitian sebelumnya terkait merdeka belajar menyebutkan Ki Hadjar Dewantara memandang pendidikan sebagai pendorong bagi perkembangan siswa, yaitu pendidikan mengajarkan untuk mencapai perubahan dan kebermanfaatan bagi lingkungan sekitar. Merdeka belajar merupakan salah satu bentuk implementasi nilai-nilai pembentuk karakter bangsa dimulai yang dari pembenahan sistem pendidikan dan metode belajar. Diharapkan merdeka belajar dapat memberikan perubahan ke arah yang lebih baik serta memberikan manfaat pada lingkungan (Ainia, 2020). Hal ini menjadi dorongan perlu segera diterapkannya sistem merdeka belajar di sekolah dasar.

Berdasarkan permasalahan yang disampaikan serta untuk melengkapi penelitian terdahulu terkait permasalahan pembelajaran IPA selama daring dan merdeka belajar, mencoba melakukan analisis terhadap pembelajaran daring khususnya pada mata pelajaran IPA dengan mengkaitkannya terhadap program Merdeka Belajar yang diluncurkan pemerintah. Penelitian difokuskan pada beberapa kabupaten di Jawa Tengah yang dirasa mampu menggambarkan kondisi pembelajaran secara daring khususnya pada pelajaran IPA. Oleh karena itu peneliti membuat penelitian dengan judul "Analisis Pelaksanaan Pembelajaran IPA Secara Daring Selama Masa Pandemi untuk Mengakselerasi Merdeka Belajar di Sekolah Dasar Se-Jawa Tengah”. Diharapkan penelitian ini bisa menjadi bahan penelitian selanjutnya untuk menuntaskan permasalahan pembelajaran selama daring dan juga bisa memberikan inspirasi bagi guru dan peneliti lain dalam mengembangkn program merdeka belajar yang sudah diluncurkan pemerintah agar bisa berjalan sesuai harapan.

\section{Metode Penelitian}

Penelitian ini dilakukan dengan metode deskriptif kualitaif untuk memberikan penjabaran tentang hasil identifikasi terkait miskonsepsi yang dialami oleh siswa SD dalam materi pembelajaran IPA. Adapun objek penelitian berasal dari guru se-Jawa Tengah yang meliputi daerah seperti Bantul, Blora, Boyolali, Grobogan, Magelang, Kabupaten Semarang, Karanganyar, Kebumen, Kendal, Klaten, Kota Semarang, Kudus, Pati, Pekalongan, Salatiga, Sragen, Sukoharjo, Surakarta, dan Wonogiri. Fokus objek penelitian saat ini adalah tujuh kabupaten dengan minimal jumlah responden lima orang guru yaitu Karanganyar, Kebumen, Klaten, Kota Semarang, Pati, Sukoharjo dan Wonogiri. Responden mengajar diberbagai kelas dengan presentase $15 \%$ mengajar di kelas 1, 11,3\% mengajar di kelas 2, 11,2\% mengajar di kelas 3, 12,5\% mengajar di kelas 4, 20\% mengajar di kelas 5, dan 16,2\% mengajar di kelas 6, yang di tentukan berdasarkan teknik purposive sampling. Selanjutnya teknik pengumpulan data dilakukan melalui wawancara dengan metode CRI (Certainly of Response Index). Data yang telah diperoleh kemudian direduksi, disajikan, dan disimpulkan serta diverifikasi sebagaimana proses analisis penelitian kualitatif (Rochmah, 2019).

Dalam angket peneliti menanyakan tiga point penting yang nantinya dikembangkan dalam jurnal penelitian ini, yaitu proses pembelajaran IPA di sekolah dasar, pelaksanaan pembelajaran daring selama wabah covid-19, dan mengenai kebijakan pemerintah terkat merdeka belajar. 


\section{Hasil dan Pembahasan}

Wabah covid-19 memaksa guru untuk dapat melakukan inovasi pembelajaran dengan memanfaatkan kemajuan teknologi saat ini. Berbagai upaya dilakukan agar pembelajaran tetap berlangsung meskipun dilarang untuk melakukan pembelajaran secara tatap muka. Pembelajaran IPA tentunya sulit untuk melakukan pembelajaran tanpa memberikan penjelasan secara langsung kepada siswa. Melihat kesulitan yang dihadapi guru untuk menghadapi peraturan baru dalam penyelenggaraan pendidikan selama wabah, pemerintah membuat beberapa kebijakan melalu program Merdeka Belajar diantaranaya Seri Guru Belajar, program PembaTIK, bantuan bagi peserta didik dan pengajar untuk menunjang pelaksanaan pembelajaran daring. Guru juga diberi banyak program peningkatan kualitas kerja dengan salah satunya diadakan Program Profesi Guru (PPG). Implementasi kebijakan Merdeka Belajar di tengah pandemi COVID-19 dilaksanakan melalui penguatan proses pembelajaran berbasis teknologi yang telah dimiliki sekolah. Penguatan pertama dilakukan melalui peneguhan kurikulum internal sekolah dengan mengacu pada kebijakan Merdeka Belajar dan pelaksanaan protokol upaya pencegahan COVID-19 di lembaga pendidikan. Penguatan kedua dilaksanakan melalui penguatan pola pengajaran berbasis web learning dengan pembelajaran daring asinkron (Mardiana, 2020).

Sayangnya sosialisasi yang dilakukan oleh pemerintah masih kurang luas sehingga mengakibatkan minimnya pengetahuan guru mengenai program-program yang sudah dibuat oleh pemerintah untuk meningkatkan pendidikan di Indonesia. Guru mungkin tau tentang program Merdeka Belajar namun belum mengetahui isi dari program tersebut. Hal ini terlihat melalui presentase guru yang bisa menjawab dengan benar jumlah episode yang sudah diluncurkan oleh program merdeka belajar, hanya $31,3 \%$ guru bisa menjawab pertanyaan ini.

\footnotetext{
Sepengetahuan Anda berapa jumlah episode dalam Merdeka Belajar 80 responses
}

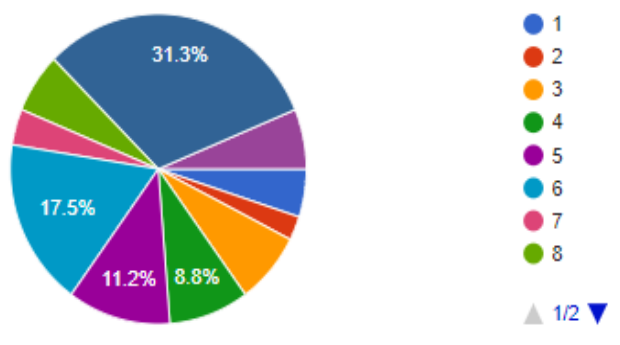

Program yang dimiliki Merdeka Belajar, pemerintah menyiapkan berbagai seminar dan diklat yang bisa dimanfaatkan guru secara online. Hanya saja 52,5\% guru jarang mengikuti seminar dan diklat tersebut secara sadar mandiri. Hal ini sangat 
disanyangkan karena program ini sudah dibuat dengan sedemekian baiknya namun kurang diminati oleh guru.

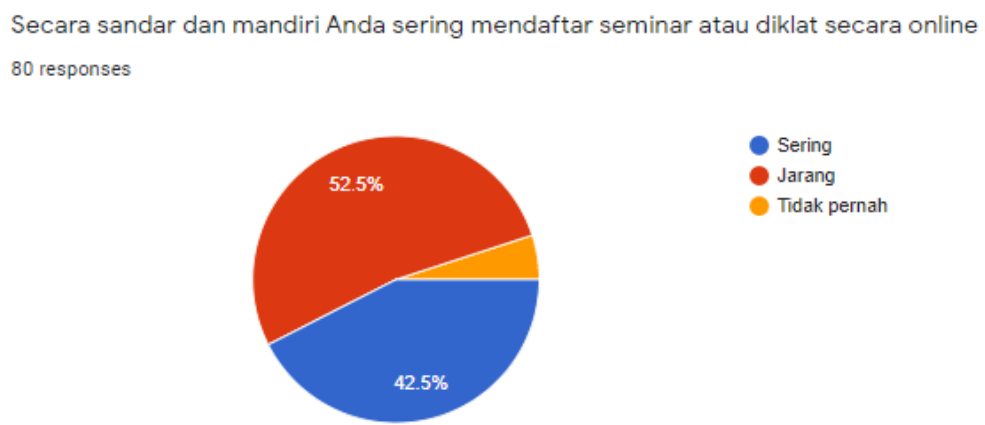

Kurang diminatinya seminar dan diklat yang sudah disiapkan oleh pemerinta bisa jadi diakibatkan oleh kurangnya perangkat teknologi seperti komputer, tablet, atau wifi yang ada di sekolahan, sehingga menyurutkan minat guru saat ingin mengikuti program tersebut.

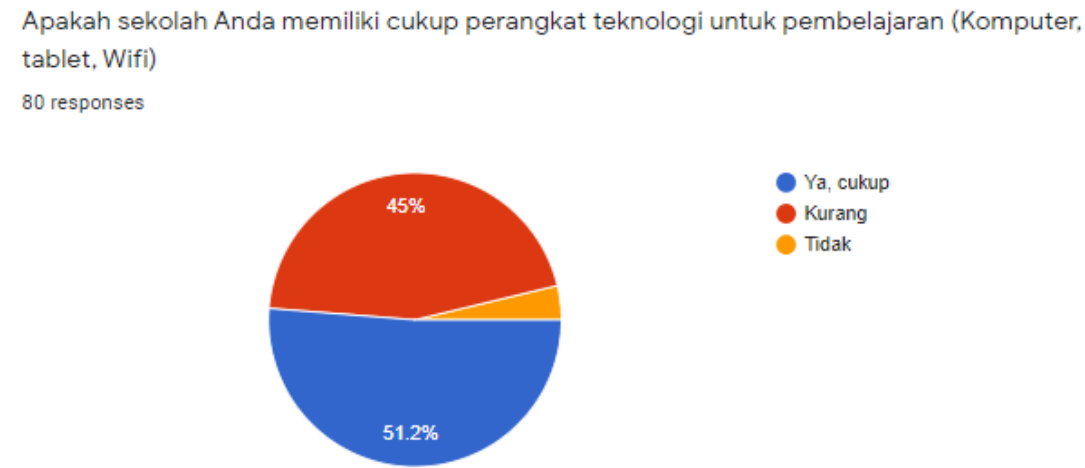

Berbagai program yang diluncurkan pemerintah melalui Merdeka Belajar tersebut tentunya diharapkan bisa membantu meningkatkan proses Pembelajaran secara daring. Kesulitan yang dihadapi guru selama pembelajaran daring diharapkan bisa diselesaikan dengan berbagai program dari pemerintah tersebut. Sebanyak 56,3\% guru menjawab bahwa mereka senang saat melakukan pembelajaran daring, sayangnya ni tidak diimbangi dengan perangkat komunikasi atau gawai yang dimiliki siswa masih ada $41,3 \%$ siswa yang belum memiliki gawai yang memungkinkan dilakukannya pelaksanaan pembelajaran secara daring ditambah $43,8 \%$ guru menyampaikan kondisi akses internet di daerahnya kurang lancar dan tidak stabil. 


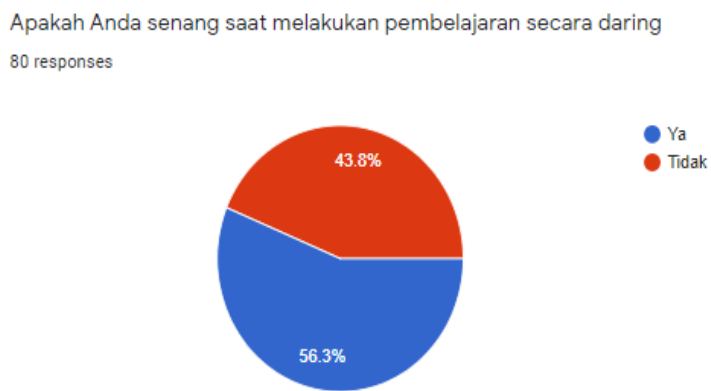

Pembelajaran daring menjadi salah satu tantangan yang dihadapi oleh guru adalah ketika hendak melakukan kegiatan evaluasi. Ada beberapa faktor pendukung guru dalam proses pembelajaran daring yaitu ketersediannya handphone, kuota dan jaringan internet yang stabil. Selain adanya faktor yang mendukung dalam pembelajaran daring terdapat juga beberapa faktor penghambat guru dalam pembelajaran daring. Faktor penghambat tersebut diantaranya adalah belum semua peserta didik memiliki handphone dan masih banyak orang tua sibuk bekerja (Putria et al., 2020).

Banyak guru yang masih kesulitan memanfaatkan aplikasi online yang tersedia untuk melakukan evaluasi pembelajaran. Hal ini terlihat dengan adanya 53,8\% guru bisa membagikan soal secara online namun untuk evaluasinya dilakukan dengan mengumpulkan atau mengirin jawaban langsung ke sekolah.

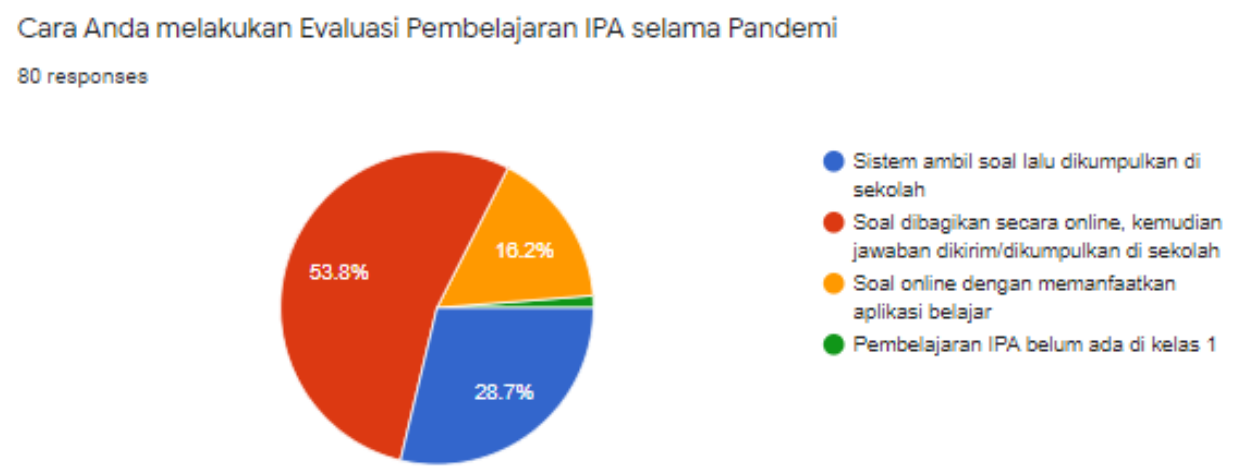

Salah satu pelajaran yang berdampak terhadap pembelajaran daring adalah pelajaran IPA. IPA merupakan salah satu pelajaran yang memerlukan penjelasan secara tatap muka serta praktik untuk menyampaikan langkah-langkah penyelesaian masalah (Hafidz Rasyidiana, 2021). Untungnya sebanyak 92,5\% guru sudang membuat RPP khusus untuk diterapkan pada pembelajaran di masa pandemi. Selain merancang perangkat pembelajaran IPA secara mandiri guru juga memanfaatkan kelompok KKG dan internet untuk mempermudah pembuatan perangkat pembelajaran IPA. Pelaksanaan pembelajaran IPA diharapkan guru tidak hanya mengembangkan komponen kognitif namun juga sikap serta keterampilan proses sains. Guru 
diharapkan bisa melakukan pembelajaran berbasis masalah sehingga pembelajaran bisa langsung terhubung dengan lingkungan alam sekitar siswa. Sebanyak 96,3\% guru senang mengajak siswa melakukan pengamatan dan $73,8 \%$ guru sudah menerapkan pembelajaran berbasis masalah pada siswanya.

\section{Kesimpulan}

Pembelajaran daring pada pembelajaran IPA sebenarnya merupakan suatu terobosan baru dalam dunia pendidikan agar pendidikan dapat berjalan secara luas tanpa terhalang oleh wilayah yang membatasi, dimana siswa dan guru bisa melakukan pembelajaran tanpa saling bertemu secara fisik. Sayangnya hal ini belum di dukung dengan saran prasaran. Dilihat dari sisi kepemilikan gawai dan perangkat komunikasi untuk pembelajaran daring masih banyak daerah yang masih kesulitan untuk memenuhi kebutuhan ini. Kesadaran yang dimiliki guru untuk mengembankan keprofesiannya juga diharapkan bisa mendukung pelaksanaan pembelajaran daring selama masa pandemi. Beberap guru secara sadar dan mandiri sudah mau melakukan pengembangan keprofesiannya dengan mengikuti seminar atau diklat online yang disediakan oleh pemerintah. Hal ini menjadi salah satu upaya pemerintah dalam mengatasi permasalahan yang muncul akibat pembelajaran yang dilakukan secara daring. Melalui program Merdeka Belajar diharapkan siswa dan guru dapat terfasilitasi dalam peningkatan mutu penyelenggaraan pendidikan di daerah masing-masing. Ketika mutu pembelajaran meningkat maka pembelajaran yang selama ini dirasa sulit untuk diajarkan menjadi mudah karena peningkatan sumber daya manusia.

Salah satu pelajaran yang dianggap cukup sulit untuk dilaksanakan pada saat pembelajaran dari adalaha pelajaran IPA. Pelajaran IPA tidak hanya menuntut aspek kognitif saja melainkan juga aspek sikap dan keterampilan proses sains. Dalam hal ini guru secara sadar harus mampu mengembangkan pembelajaran IPA yang telah disesuaikan dengan lingkungan siswa agar tercipta pembelajaran yang bermakna dan berkelanjutan. Pembelajaran akan efektif jika diketahui kebutuhan belajar penggunanya dalam hal ini baik mahasiswa ataupun pelajar. Kondisi awal pembelajaran perlu diketahui terlebih dahulu dalam pengembangan suatu program, sehingga efektifitas pembelajaran yang rancang akan sesuai dengan kebutuhan dan tantangan yang dihadapi. 


\section{BIBLIOGRAFI}

Absari, S. A. N. (2020). Pembelajaran Daring Pada Mata Pelajaran Ipa Terpadu Di Sekolah Berbasis Pesantren (Studi Kasus Di Smp Ya Bakii 1 Kesugihan Cilacap Tahun Pelajaran 2020/2021).Google Scholar

Ainia, D. K. (2020). Merdeka Belajar Dalam Pandangan Ki Hadjar Dewantara Dan Relevansinya Bagi Pengembangan Pendidikan Karakter. Jurnal Filsafat Indonesia, 3(3), 95-101. Google Scholar

B, F., \& Ramli, E. S. S. (2021). Analisis Situasi Pembelajaran Ipa Sekolah Dasar Dengan Metode Daring Selama Masa Wabah Covid-19. Edukatif : Jurnal Ilmu Pendidikan, 3(1), 255-260. Google Scholar

Davies, P. D. O. (2002). Multi-drug resistant tuberculosis. CPD Infection, 3(1), 9-12. Google Scholar

Depdiknas. (2003). Undang-Undang Republik Indonesia No 20 Tentang Sistem Pendidikan Nasional. Jakarta: Direktorat Pendidikan Menengah Umum, 6. Google Scholar

Hafidz Rasyidiana. (2021). Problematika Pembelajaran Daring Pada Mata Pelajaran Sains (IPA) Tingkat Dasar Di Masa Pandemi Covid-19. Jurnal Basicedu, 5(4), 1060-1066. Google Scholar

Hanafy, M. S. (2014). Konsep dan Pembelajaran. Lentera Pendidikan, 17(1), 66-79. Google Scholar

Handayani, N. A., \& Jumadi, J. (2021). Analisis Pembelajaran IPA Secara Daring pada Masa Pandemi Covid-19. Jurnal Pendidikan Sains Indonesia, 9(2), 217-233. Google Scholar

Maison, M., Kurniawan, D. A., \& Pratiwi, N. I. S. (2020). Pendidikan sains di sekolah menengah pertama perkotaan: Bagaimana sikap dan keaktifan belajar siswa terhadap sains? Jurnal Inovasi Pendidikan IPA, 6(2), 135-145. Google Scholar

Mardiana, D. (2020). Merdeka Belajar di Tengah Pandemi COVID-19: Studi di Sekolah Menengah Pertama di Indonesia Pandemi COVID-19 telah menjadi diskursus hangat sekaligus trending topic pada berbagai riset di bidang pendidikan dewasa ini ( Sintema , 2020 ). Dampak virus yang . 13(2), 78-91. Google Scholar

Purnamawan, N. (2021). Kadar Immature Platelet Fraction Dan Luaran Sindrom Koroner Akut Yang Disertai Pneumonia Corona Virus Disease-19. Universitas Hasanuddin. Google Scholar

Putria, H., Maula, L. H., \& Uswatun, D. A. (2020). Analisis Proses Pembelajaran dalam Jaringan (DARING) Masa Pandemi Covid- 19 Pada Guru Sekolah Dasar. Jurnal 
Rose Andriyani Saputri

Basicedu, 4(4), 861-870. Google Scholar

Rochmah, L. (2019). Peningkatan Hasil Belajar IPS Sub Tema Manusia dan Lingkungan melalui Model Sains Teknologi Masyarakat berbantuan Media Question Card pada Siswa Kelas VA MIN Salatiga Tahun Pelajaran 2019/2020. Iain Salatiga. Google Scholar

Sadikin, A., \& Hamidah, A. (2020). Pembelajaran Daring di Tengah Wabah Covid-19. Biodik, 6(2), 109-119. Google Scholar

Sourial, N., Longo, C., Vedel, I., \& Schuster, T. (2018). Daring to draw causal claims from non-randomized studies of primary care interventions. Family Practice, 35(5), 639-643. Google Scholar

Susilo, A., Rumende, C. M., Pitoyo, C. W., Santoso, W. D., Yulianti, M., Herikurniawan, H., Sinto, R., Singh, G., Nainggolan, L., Nelwan, E. J., Chen, L. K., Widhani, A., Wijaya, E., Wicaksana, B., Maksum, M., Annisa, F., Jasirwan, C. O. M., \& Yunihastuti, E. (2020). Coronavirus Disease 2019: Tinjauan Literatur Terkini. Jurnal Penyakit Dalam Indonesia, 7(1), 45. Google Scholar

\section{Copyright holder:}

Rose Andriyani Saputri (2021)

First publication right:

Syntax Idea

This article is licensed under:

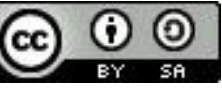

